\title{
谷川岳周辺における山岳景観の生理・心理的効果に 関する基礎的研究
}

A Fandamental Study on Physiological and Psychological Effects of the Mountain Landscapes around Mt.Tanigawa.

\author{
多田 充 ${ }^{*}$ 金 恩一 ${ }^{* *}$ 藤井英二郎*** \\ Mitsuru TADA Eunil KIM Eijiro FUJII
}

摘要 : 山容および表面の被覆の異なる山岳景観が人間に与える生理・心理的影響について比較するた め, 樹木に覆われた山と急峻な谷川岳一ノ倉沢を対象に実験的に検討した。現地で被験者から脳波, 自律神経機能を測定し，同時にアンケートを行った。その結果，山ではーノ倉沢に比べて安全感と快 適感が低かった。脳波の $\alpha$ 波発生量は山では一ノ倉沢に比べて前頭部中央において相対的に高く、脳 の同部位の活動が異なることが示唆された。両対象は言語を介した評価，感情のみならず，身体的な 反応にも異なる影響を与えていると考えられる。また性によって山岳景観の評価，脳波や自律神経の 反応が異なり，男性はより分析的に，女性はより感情的に捉えていた。

\section{1. 研究の目的}

景観が人間に与える生理・心理的な効果は経験的には知られて いるが, 実証的な研究は少ない。影観はさまざまな要素によって 組み立てられており，その生理・心理的な効果を明らかにするた めには, まず特徵的で少ない構成要素からなる景観について研究 する必要があるものと思われる。そこで本研究では景観のうち山 岳景観が人間に与える生理・心理的効果を実験的に検討すること を目的とした。特に，山容および表面の被覆について比較検討す るために，樹木におおわれた山と急峻な岩山である谷川岳一ノ倉 沢を対象とした。

\section{2. 研究の方法}

（1）対象，日時および被験者について

実験地は群馬県水上町一ノ倉沢の標高約 $1000 \mathrm{~m}$ の平坦地で, 山岳以外の景観構成要素がなるべく入らないような場所を選んだ。 実験地は国道 291 号線に続く林道の路上であるが車両の通行が制 限されており，また実験中は歩行者も遮断し て被験者が実験に専念できるように配慮した。 提示景観は樹木に覆われた山としては実験地 の南方に位置する山（標高約 $1250 \mathrm{~m} ：$ 以下 ヤマと略す）を，急峻な岩山としては実験地 の西方に位置する谷川岳一)倉沢（稜線部標

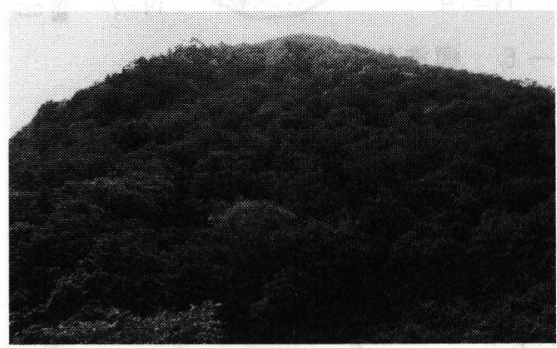

写真一1 提示景観(ヤマ)

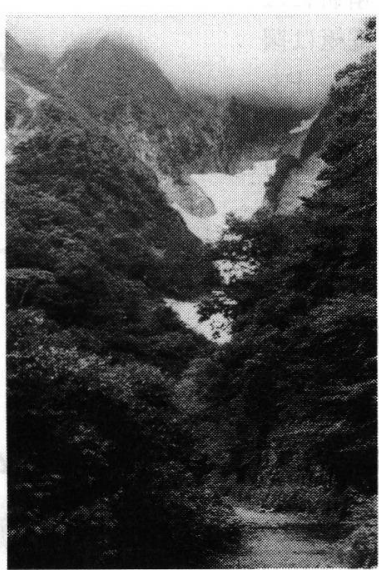

写真一 2 提示景観(クラ)

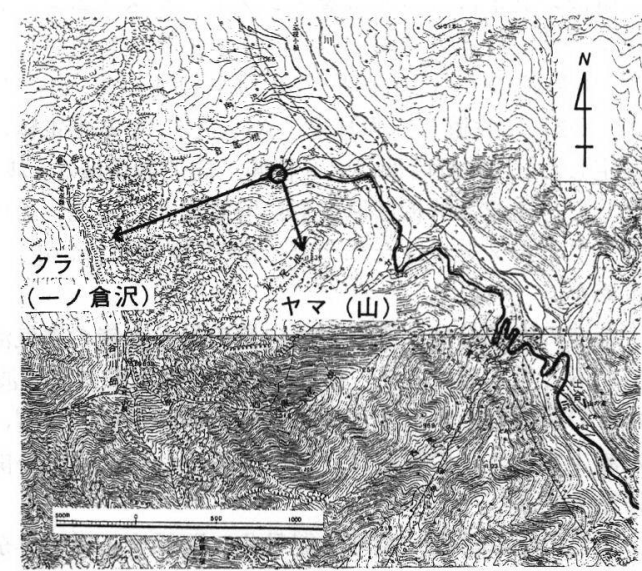

図一1＼cjkstart実験地および対象の位置

*千葉大学大学院園芸学研究科 ${ }^{* *}$ 千葉大学大学院自然科学研究科 ${ }^{* * *}$ 千葉大学園芸学部緑地 $\cdot$ 環境学科 


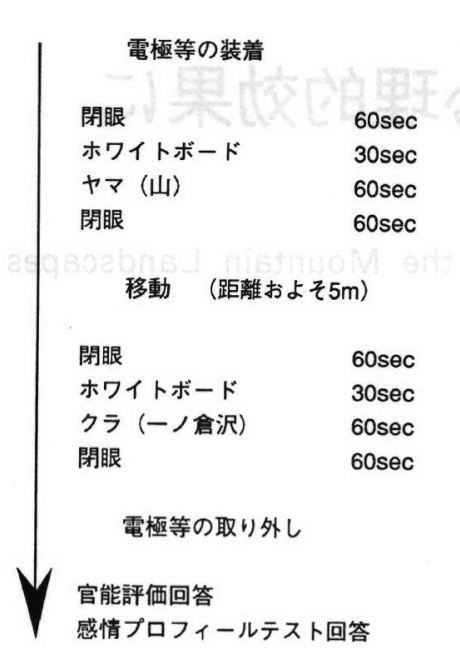

図一2 測定順序

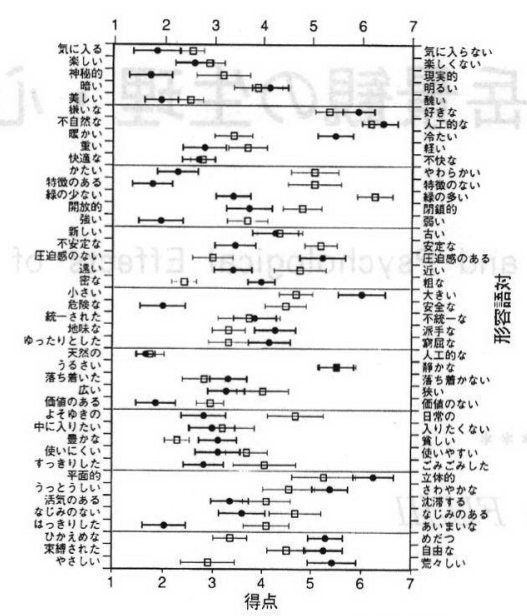

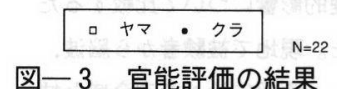

\begin{tabular}{|c|c|c|c|c|c|c|c|}
\hline & \begin{tabular}{|c|c|c|} 
& $\mathrm{m}$ & $\mathrm{m}$ \\
\end{tabular} & & \begin{tabular}{|l|l|l|}
1 & "I & II \\
\end{tabular} & 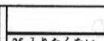 & 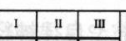 & & \begin{tabular}{c|c|c|c|} 
& " \\
\end{tabular} \\
\hline 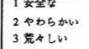 & 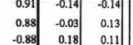 & 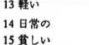 & 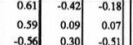 & 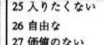 & 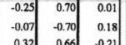 & 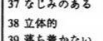 & 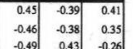 \\
\hline 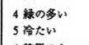 & 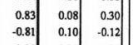 & 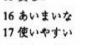 & 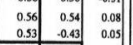 & 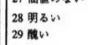 & 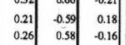 & 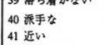 & 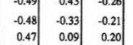 \\
\hline 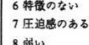 & 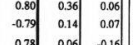 & 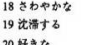 & 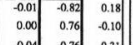 & 步 & 0.570006 & 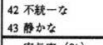 & 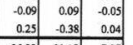 \\
\hline & 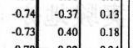 & 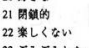 & 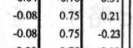 & 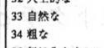 & 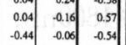 & & \\
\hline & 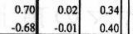 & & 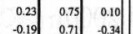 & 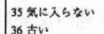 & $\begin{array}{llll}0.28 & 0.040\end{array}$ & & \\
\hline
\end{tabular}
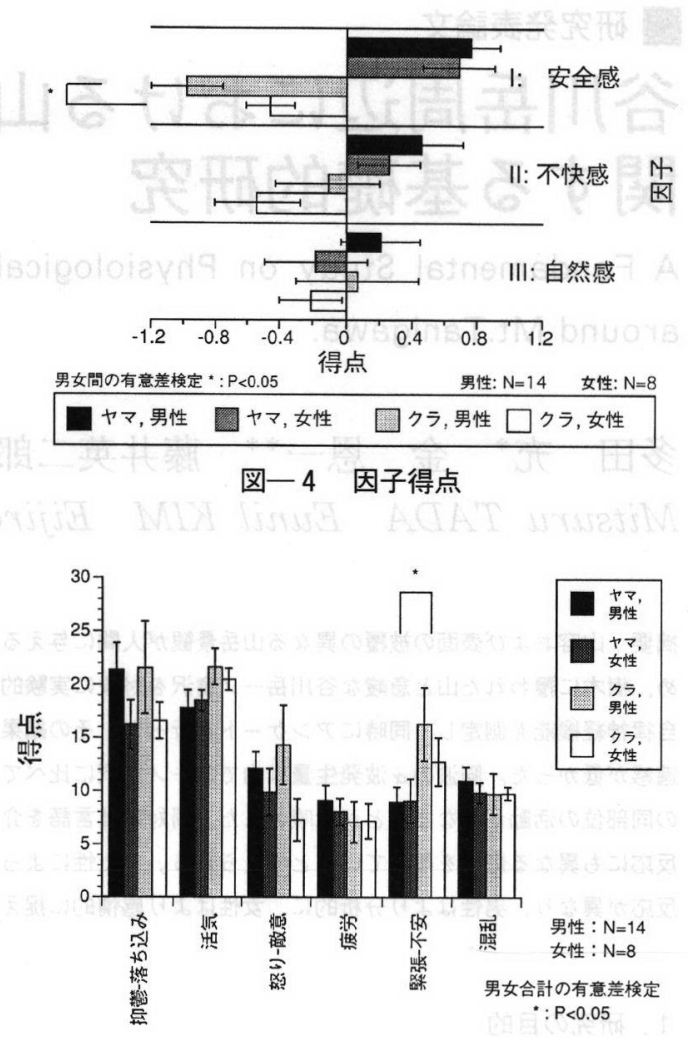

図一5＼cjkstart感情プロフィールテストの結果

\section{(3)測定および解析方法}

今回解析に用いたのは官能評価，心理テスト，脳波と自律神経 機能（血圧，心拍）の各項目である。

( I ) 官能評価

官能評価はSD 法を使用し，質問紙は 43 対の形容語対につい て7段階で回答するように作成した。質問紙への記入は実験の前 後に心理テストと同時に対象を見ながら行った。

(ii)心理テスト

心理テストは感情プロフィールテストを使用した。感情プロフィー ルテストは自己記入式質問紙法のひとつで, 被験者の性格傾向で はなく,より一時的な感情状態を評価するものである ${ }^{1)}$ 。本実験 では荒記・横山の日本語版を使用した。

\section{( iii) 脳波}

脳波の測定は日本光電製テレメトリシステムを用い，解析には キッセイコムテック製 BIMTUS システムを使用した。電極は国 際 10-20 法のうち 10 箇所 (F3, Fz, F4, C3, C4, P3, Pz, P4, O1，O2）に設置し，両耳梁（A1，A2）を基準電極に単極誘導で 測定した ${ }^{2)}$ 。解析時間は 2.5 秒間, 周波数帯域は $\alpha$ 波 $(8 \sim 13 \mathrm{~Hz})$ とした。周波数解析は原波形に前処理として $4 \sim 40 \mathrm{~Hz}$ のバンド パスフィル夕をかけたうえで, FFT 変換を行い電圧 $(\mathrm{mmV})$ を 求めた。

脳波の大部分は大脳皮質灰白質の最も表層の電気活動を反映し ていると考えられる ${ }^{3)}$ 。脳波は閉眼安静状態では $\alpha$ 波を中心とし たものが観察されるが, 感覚刺激や精神活動, 覚醒によって $\alpha$ 波 は減少する。この現象はシナプスがそれぞれ活動を開始したため に発生する ${ }^{4}$ 。

また大脳は言語, 論理と記号化に関係する優位半球（多くは左 半球）と空間的，時間的な認識に関係する劣位半球（多くは右半 球）に分けられる。さらに皮質には機能が局在し, 前頭葉は意志 や感情, 側頭葉は言語や記憶, 頭頂葉は知覚, 認知や運動, 後頭 葉は視覚と関係が深いといわれる516)。
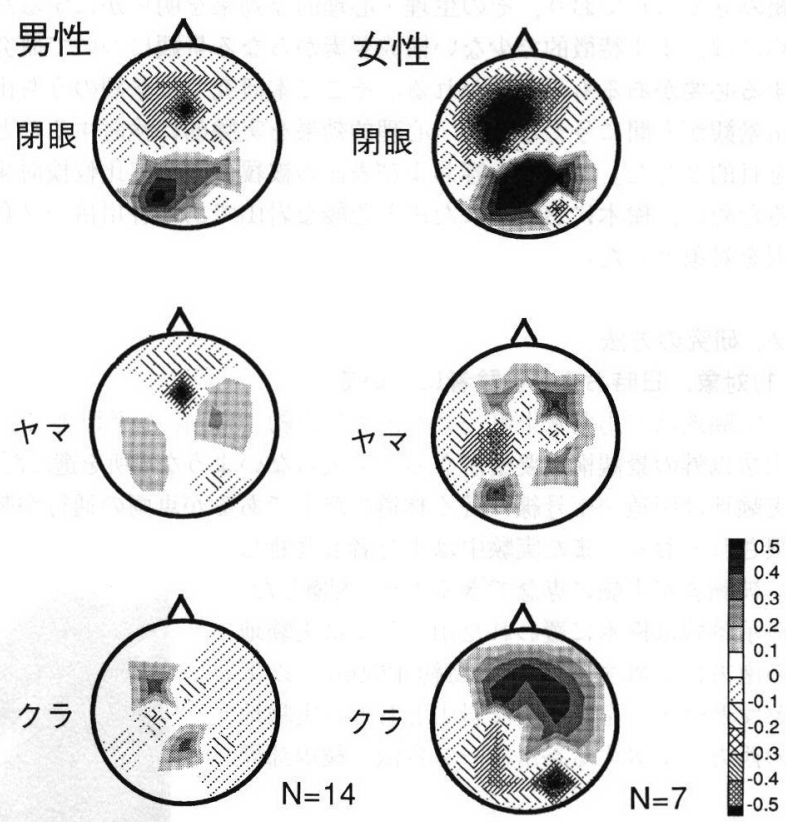

図一 6 標準化 $\alpha$ 波発生量

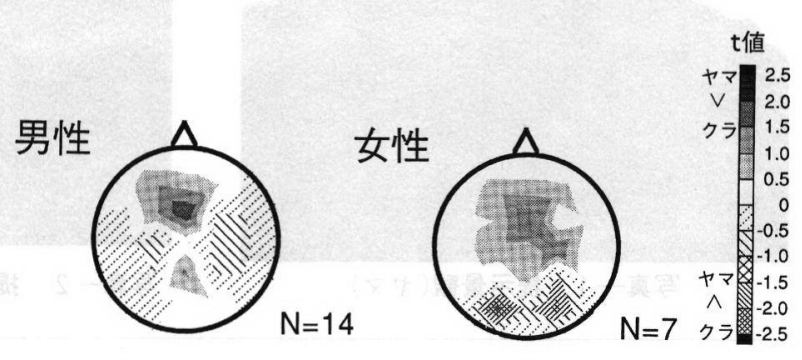

図一，標準化 $\alpha$ 波発生量の $\mathrm{t}$ プロフィル 
以上のような知見から $\alpha$ 波の減少は当該部位周辺の大脳の賦活 を，逆に増加は活性低下を示すと推測することが可能である。 (iv) 自律神経機能

自律神経機能の活動を反映する指標として心拍，血圧を測定し た。心拍の測定には竹井機器製心拍メモリシステムを使用した。 解析には対象を見ている間の心拍 RR 間隔（以下 RRtime と略 す) と RR 間隔の変動係数（以下 $\mathrm{cvRR}$ と略す）を求めた。

血圧の測定はオメダ製フィナプレスシステムを使用し，指先に カフ（加圧帯）を装着, 高さを固定して行った。血圧は脳波測定 後に続けて測定し，解析には 15 秒間のデータを用いた。

検討には心拍，血圧とも対象を見る直前の閉眼時に対する\%值 を用いた。

交感神経系が優位になると RRtime と cvRR は減少，収縮期 血圧は上昇し, 副交感神経系が優位になると逆の反応を示す718)。

\section{3. 結果}

\section{(1)官能評価}

官能評価の結果を図一 3 に示す。この結果を主因子分析し $3 つ$ の因子を抽出した。回転後の因子負荷量を表一 1 に示す。I 因子 は安全な, やわらかい, 豊かな, といった形容語の因子負荷量が 高く, 安全感（寄与率 $26.39 \%$ ）と命名した。II 因子はうっとう しい，嫌いな，暗いといった形容語の因子負荷量が高く，不快感 (寄与率 $21.18 \%$ ) と命名した。III 因子は天然の, 自然な, 古い といった形容語の因子負荷量が高く，自然感（寄与率 7.37\%） と命名した。

因子得点の結果を図一 4 に示す。男女ともクラはヤマに比べて 安全感が低く, 不快感が低い, つまり危険だが快く好きだという 結果になった。自然感は同じ性では対象差は小さく, 性差の方が 大きくなっている。対象に関わらず男性は女性に比べて自然感が 高いと評価している。

性差は自然感の他にもあり, 男性は女性よりも安全感への反応 性が高かった。特にクラでは男女間に統計的に有意な差が見られ た。また女性は男性よりもクラ, ヤマともに不快感を低く評価す る傾向があった。

(2)感情プロフィールテスト 感情プロフィールテストの 結果を図一 5 に示す。男女と も活気，緊張一不安はクラて 高く, 疲労, 混乱は山で高く なる傾向が見られた。男女を 合計して検定をしたところ， 緊張一不安には統計的な有意 差が見られた。

性差では怒り一敵意が男性 はクラで高いのに対し, 女性 では逆にクラでは低くなる傾 向が見られた。

\section{(3)脸波}

$\alpha$ 脳波の発生量は個人によっ て差異があるため, 被験者全 体の傾向を知るために $\alpha$ 波の 発生量を各被験者, 各対象毎 に平均值で標準化した。この 標準化した発生量（以下発生 量という）を測定全電極につ いて被験者間で平均した結果 を図一6に示す。

閉眼時は男女とも前頭部で
発生量が低く, 後頭部で高くなっている。ヤマでは男性は発生量 の低い部位が前頭部に，高い部位が右頭頂部に見られ，女性では 発生量の低い部位が左頭頂部に, 高い部位が右前頭と左後頭部に 見られた。クラでは男性は発生量が低い部位が右半球全体に, 高 い部位が左半球前頭部と後頭部中央に見られ，女性は発生量の高 い部位が前頭部から右頭頂部にかけて，低い部位が後頭部から左 頭頂部にかけて見られた。

次にヤマとクラでの発生量を比較するために, 各被験者のヤマ とクラでの発生量を $\mathrm{t}$ 検定し, $\mathrm{t}$ プロフィルを求めた。その結果 を図一7に示す。t值の高い部位はクラではヤマよりも $\alpha$ 波の発 生量が多く脳の活性は低い,一方 $\mathrm{t}$ 值の低い部位では $\alpha$ 波の発生 量が少なく活性が高いことを示している。男性では t 值の低い部 位が頭頂部の特に右側に見られ，高い部位が前頭部中央と頭頂部 中央に見られた。女性では $\mathrm{t}$ 值の低い部位が後頭部に，高い部位 が前頭部から頭頂部右側にかけて見られた。従って男女共に前頭 部中央に $\mathrm{t}$ 值の高い部位が見られることになる。前頭葉は高等精 神作用と関係があり, ヤマではクラよりもこの機能が賦活されて いる可能性が示された。性差については $\mathrm{t}$ 值の低い部位が男性で は頭頂部の左右側であるのに対して女性では後頭部であった。ク ラでは男性は感覚や図形的な認知に関係する頭頂葉が，女性は視 覚を司る後頭葉がより賦活されていると考えられる。上述の結果 よりクラではヤマに比べて，男性は対象の認知や分析あるいは臨 場感を感じ，女性は視覚，図形に注目する傾向があるのではない かと推測される。他の測定項目の性差とも考えあわせると，男女 の山岳景観に対する認知が異なっている可能性が示唆された。

\section{(4)自律神経機能}

心拍の解析の結果を図一 8,9 に示す。RRtimeはヤマ, ク ラとも男性女性とも 1 ～2 ポイント程度の変化であった。cvRR は男性はヤマではやや減少し, クラではヤマに比べてさらに 12 ポイント減少し，クラとヤマの間では統計的に有為な差が見られ た。女性はヤマ, クラとも数ポイントの変化であった。

血圧の解析の結果を図一10,11 に示す。収縮期血圧は男性で は, クラではヤマよりもやや高くなる傾向が見られ，女性では逆 にクラではヤマよりも低くなる傾向が見られた。拡張期血圧は男 性，女性ともクラではヤマよりも高くなる傾向が見られた。

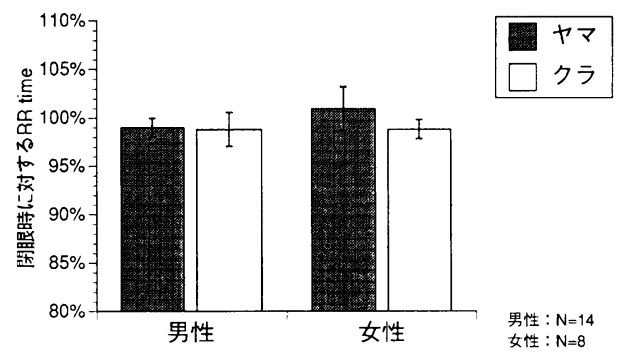

図一8 心拍R R間隔

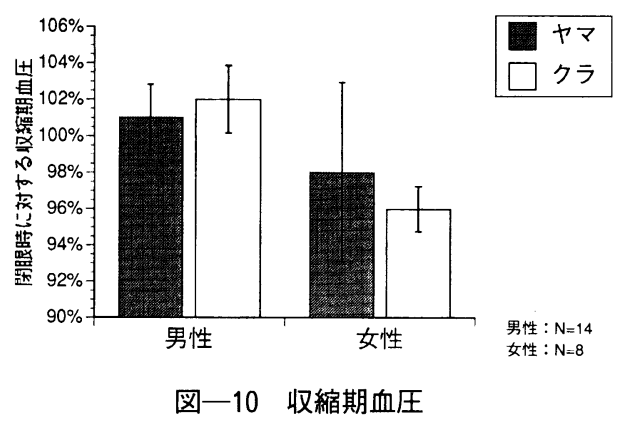

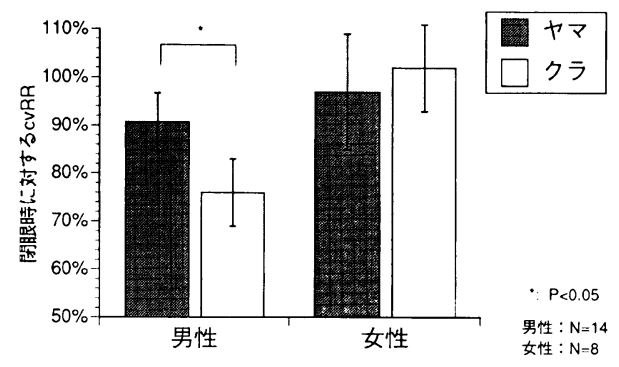

図一9 心拍 R R 間隔変動係数

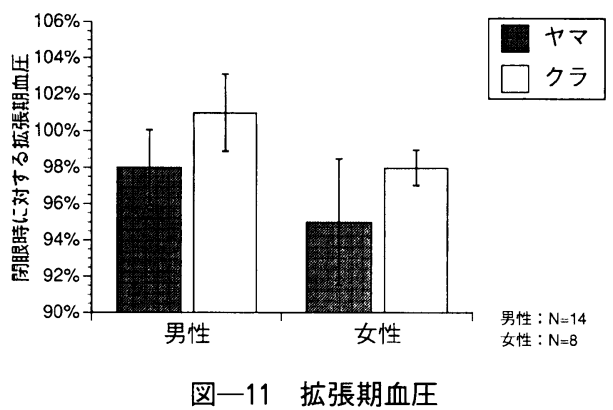


表一2 被験者の反応のまとめ

\begin{tabular}{|c|c|c|c|c|}
\hline & & \multirow{2}{*}{$\begin{array}{l}\text { 被験者の反応 } \\
\text { (男女共通) }\end{array}$} & \multicolumn{2}{|c|}{ 性差 } \\
\hline & & & 男性 & 女性 \\
\hline \multirow{2}{*}{ 官能評価 } & 山 & 安全·不快 & \multirow[b]{2}{*}{ 安全感への反応性が高い } & \multirow[b]{2}{*}{ 快適感が強い } \\
\hline & 一ノ倉沢 & 危険 - 快適 & & \\
\hline \multirow{2}{*}{ 感情プロフィールテスト } & 山 & 緊張が低い & 怒り一敵意が低い & 怒り一敵意が高い \\
\hline & 一ノ倉沢 & 繄張が高い & 怒り一敵意が高い & 怒り一敵意が低い \\
\hline \multirow{3}{*}{ 脳波（標準化 $\alpha$ 波発生量） } & 山 & 前頭部中央で低い & 頭頂部特に右側で低い & 後頭部で低い \\
\hline & 一ノ倉沢 & 前頭部中央で高い & 頭頂部特に右側で高い & 後頭部で高い \\
\hline & & & \multicolumn{2}{|c|}{$\begin{array}{c}\text { 山と一ノ倉沢のt值を男女で比較すると } \\
\text { 頭頂部では左側よりも右側でより大きい差がある }\end{array}$} \\
\hline \multicolumn{2}{|l|}{ 自律神経機能·副交感神経 } & & 山でより優位 & 一ノ倉沢でより優位 \\
\hline
\end{tabular}

男性では，ヤマではクラに比べて $\mathrm{cvRR}$ が高く，副交感神経 系が優位であった。女性では cvRR, 収縮期血圧はむしろ男性の 逆の傾向が見られ，副交感神経系はクラでより優位になっている 可能性が示唆された。

\section{4. 考察}

(1)対象について

ヤマもクラも仰角は約 25 度程度であり, 差異は山までの距離, スカイラインと地形，表面の被覆状態である。

Dreyfessによれば，頭部を動かさない場合の眼球の動きは仰 角 25 度までであり，正面を見ている場合に対象物の色を認識で きる範囲の仰角は約 30 度までである ${ }^{9)}$ 。本実験では仰角が 30 度 に達していないので，対象全体を視野に入れることができるもの と考えられる。樋口は仰角が 20 度近くなると山腹斜面が壁立的 に立ち現れ，山を見るというよりは山が存在するという感じを持 つとしている ${ }^{10)}$ ので, 本実験では山をいわゆる肌で感じる状態 であると考えられる。距離はヤマが $500 \mathrm{~m}$ ，クラが $2000 \mathrm{~m}$ であ り，桶口によれば両方とも中距離景 ${ }^{11)}$ に相当する。また，スカ イラインはヤマが丸みを帯びた凸形であるのに対して, クラはい くつもの尾根が重なった直線が複雑に絡み合った形をしている。 クラの複雑なスカイラインは雲がかかった状態でも充分確認でき た。さらに，雪溪が眼前に立ち上がるような沢の景色をつくり出 し, 特徵的な山岳景観を形成している。表面の被覆はヤマが落葉 樹を中心とした樹木に覆われているのに対して，クラは植物に乏 しく，岩石や雪が含まれている。
(2)被験者の反応について

被験者の反応をまとめると表一 2 のようになる。クラに快さを 感じるのは，上述のような特徵的な山岳景観であるからだろう。 また，もし実際にクラに立つならば傾斜や足場の悪さが容易に想 像できる。被験者はその場にいたらと想像して, 危険を感じ, 緊 張したものと思われる。ヤマでの脳波 $\alpha$ 波発生量が前頭部中央に おいてクラよりも低いということは，その部位が活動しているこ とを示唆し, 今後高等精神機能との関連を検討する必要がある。

また本実験では山岳景観に対する性差もみられた。男性は安全 性に対して反応性が高く, より安全であると評価したヤマではク ラよりも副交感神経系が優位であった。脳波にみられるヤマとク ラの差も頭頂部の特に右側という感覚や図形的な認知と関係が考 えられる部分で大きかった。これらのことから男性は山岳景観に 対して客体的，分析的に認識していると推測される。

一方女性は両対象を男性に比べてより快いと評価し，さらによ り快いと評価したクラではヤマよりも副交感神経系がより優位で あった。また，脳波にみられるヤマとクラの差は後頭部で大きく， クラでは視覚処理がより活発であると考えられる。これらのこと から女性は男性に比べて山岳景観を主体的に捉え，視覚的な感受 性が強く，感情による支配が強いと考えられる。

\section{(3)今後の検討課題}

今後は被験者数と対象となる景観のタイプを増やすことと, 複 合した景観がどのように評価されるかについて研究を進める必要 があるものと思われる。

なお，本研究は日産科学振興財団の助成を受けている。

\section{参考文献}

1) 横山和仁・荒記俊一ほか (1990)：PO MS（感情プロフィール検査）日本語 版の作成と信頼性および妥当性の検討： 日本公衛誌 37, 913 917

2 ) 門林岩雄ほか編(1983)：脳波，金芳堂

3 ）馬場一雄ほか(1990）: 小児脳波と誘発
電位の臨床 : 金原出版

4 ）医学大事典（縮刷版）（1954）：南山堂

5 ) 生物学事典(1977): 岩波書店

6 ) 市岡正道ほか訳(1994)：医科生理学展 望 : 丸善

7 ) 同上

8 ）日本自律神経学会編 (1992)：自律神経
機能検査 : 文光堂

9) Henry Dreyfess (1959): The measure of man : Whitney Library of Design

10）樋口忠彦(1975）：景観の構造：技報堂 出版

11）同上

Summary: Wo compared the physiological and psychological effects between the two types of the mountain landscape around Mt.Tanigawa, which differ in the figure of mountain and in the vegetation cover. We measured EEG, autonomic nerve system functions (heartrate and hypertension) and questionnaire from the subjects inspecting a mountain coverd with forest and a rockey mountain with a snowy vally named Ichinokurasawa around Mt. Tanigawa. According to the questionnaire, at the mountain covered with forest the subjects feel more safety and unpleasant than Ichinokurasawa. EEG alpha wave's generation is relatively high around the center of parietal area at the mountain covered with ferest than Ichinokurasawa. Therefore the mountain covered with forest and Ichinokurasawa make a difference not only in sensory responses, but also in the physical responses. Moreover, the evaluation, EEG and autonomic nerve system functions are different by sex, i.e. male is considered to recognize the mountain landscapes more analytically, and female recognize more emotionnally. 